\title{
Proteome changes underpin improved meat quality and yield of chickens (Gallus gallus) fed the probiotic Enterococcus faecium
}

\author{
Aijuan Zheng ${ }^{1 \dagger}$, Jianjie Luo ${ }^{1+}$, Kun Meng ${ }^{1 \dagger}$, Jianke Li ${ }^{2}$, Shu Zhang ${ }^{1}, \mathrm{Ke} \mathrm{Li}^{1}$, Guohua Liu ${ }^{1 *}$, Huiyi Cai ${ }^{1}$, Wayne L Bryden ${ }^{3}$ \\ and Bin $\mathrm{Yao}^{1 *}$
}

\begin{abstract}
Background: Supplementation of broiler chicken diets with probiotics may improve carcass characteristics and meat quality. However, the underlying molecular mechanism remains unclear. In the present study, 2D-DIGE-based proteomics was employed to investigate the proteome changes associated with improved carcass traits and meat quality of Arbor Acres broilers (Gallus gallus) fed the probiotic Enterococcus faecium.

Results: The probiotic significantly increased meat colour, water holding capacity and pH of pectoral muscle but decreased abdominal fat content. These meat quality changes were related to the altered abundance of 22 proteins in the pectoral muscle following $E$. faecium feeding. Of these, 17 proteins have central roles in regulating meat quality due to their biological interaction network. Altered cytoskeletal and chaperon protein expression also contribute to improved water holding capacity and colour of meat, which suggests that upregulation of chaperon proteins maintains cell integrity and prevents moisture loss by enhancing folding and recovery of the membrane and cytoskeletal proteins. The down-regulation of $\beta$-enolase and pyruvate kinase muscle isozymes suggests roles in increasing the $\mathrm{pH}$ of meat by decreasing the production of lactic acid. The validity of the proteomics results was further confirmed by qPCR.

Conclusions: This study reveals that improved meat quality of broilers fed probiotics is triggered by proteome alterations (especially the glycolytic proteins), and provides a new insight into the mechanism by which probiotics improve poultry production.
\end{abstract}

Keywords: Broiler chicken (Gallus gallus), Enterococcus faecium, Carcass, Meat quality, Pectoral muscle proteome, Probiotics

\section{Background}

Poultry is a significant source of animal protein and accounts for $30 \%$ of global meat consumption [1]. Compared with beef and pork, chicken meat contains lower concentrations of fat, sodium and cholesterol and a high degree of unsaturated fatty acids and a balanced $n-6$ to $n-3$ polyunsaturated fatty acid ratio [2,3]. With the application of modern breeding technology, the major biological characteristics of meat chickens or broilers, i.e.

\footnotetext{
*Correspondence: liuguohua@caas.cn; binyao@caas.cn

${ }^{\dagger}$ Equal contributors

'Key Laboratory of Feed Biotechnology of Ministry of Agriculture, Feed Research Institute, Chinese Academy of Agricultural Sciences, Beijing 100081, P. R. China

Full list of author information is available at the end of the article
}

pectoral (breast) muscle yield, body composition, daily weight gain, feed conversion efficiency and resistance to disease, have been improved significantly [4,5]. Despite the success of breeding programs in increasing meat production, the high selection intensity has resulted in negative impacts on meat quality [6], including meat $\mathrm{pH}$, water holding capacity, texture, and colour [7-9]. Moreover, meat flavour, storage and processing quality have also decreased following selection for increased meat production $[10,11]$. As these negative effects on meat quality will impact on consumer acceptability of poultry meat [12], the physicochemical and sensory properties of broiler meat are receiving considerable research attention [13]. Water loss can reduce the nutritional value, flavor and 
tenderness of meat [14]. Moreover, $\mathrm{pH}$ is negatively correlated with water loss from muscle $[15,16]$. Thus, $\mathrm{pH}$, colour and water holding capacity of meat including drip loss and cooking loss are important parameters related to meat quality.

With reduced use of feed antibiotic growth promoters to satisfy consumers' requirement, farmers employ several strategies to maintain chicken health and improve meat quality [17-19]. Dietary supplementation with probiotics is becoming popular. The live probiotic microbes can improve the intestinal environment by inhibiting pathogens through competition for nutrients and binding sites on the intestinal epithelium, promoting antimicrobial conditions, and stimulating the immune system [20]. Positive effects of numerous probiotics organisms (Lactobacillus spp., Enterococcus faecium, Bifidobacterium bifidum, Bacillus subtilis, Streptococcus thermophdus, Pediococcus pentosaceus or Saccharomyces cerevisiae) have been reported in chickens [21-31], while a few studies have shown no improvement in bird performance with dietary addition of probiotics [32]. Importantly for consumers, dietary supplementation of broiler diets with probiotics can improve carcass characteristics [33] and meat quality [34]. However, the molecular details of how probiotics improve the meat quality remain unclear. This is a complex area as meat quality is influenced by a wide spectrum of factors, including genetics, nutrition, husbandry conditions and handling before and after slaughter [35].

Proteomics has emerged as an effective approach for delineating the molecular basis of the physiological changes in muscle during chicken growth [36]. This approach should also assist in elucidating the mechanism of probiotic action $[37,38]$. In this study, proteome changes were determined in the pectoral muscle of broiler chickens fed a probiotic to gain a better understanding of the mechanisms underlying improved carcass characteristics and meat quality induced by feeding probiotics to meat chickens.

\section{Methods}

The study described in this paper was conducted in the Feed Research Institute, Chinese Academy of Agricultural Sciences (CAAS), Beijing, China. The care and use of all experimental birds was approved by the Animal Care and Use Committee of the Feed Research Institute of the CAAS.

\section{Materials and reagents}

Microcapsules of E. faecium CGMCC 2516 [39,40] (viable count $\geq 1 \times 10^{10} \mathrm{cfu} / \mathrm{g}$; Challenge Biotechnology Ltd. Co., Beijing, China) were used in the present experiment. All reagents for 2-D DIGE were purchased from GE Healthcare (Uppsala, Sweden), Bio-Rad (Hercules, CA, USA), Roche (Mannheim, Germany), and Sigma-Aldrich (St.
Louis, MO, USA). The reagents for LC-Chip electrospray ionization quadrupole time-of-flight mass spectrometry (ESI-QTOF-MS) were purchased from Bruker Daltonics (Billerica, MA, USA), Roche, and J. T. Baker (Phillipsburg, NJ, USA).

\section{Bird management and experimental treatments}

A total of 144 one-day-old, male, Arbor Acres (AA) broiler chickens that had been vaccinated with infectious bronchitis, avian influenza, Marek's disease and Newcastle disease vaccines were purchased from Huadu Chicken Co. (Beijing, China). The chicks were randomly divided into two groups (control and treatment). Each group had 6 replicates (cages) and each replicate (cage) had 12 birds. The distribution of cages was arranged to avoid any location effects within the poultry house. The chickens were reared from 0 to 42 days and fed corn-soybean meal starter (0-21 days) and grower (22-42 days) diets (Additional file 1: Table S1) without (control) or with the probiotic $\left(>10^{6} \mathrm{cfu} / \mathrm{g}\right.$ E. faecium) for 42 days. All chickens were subject to a photoperiod of $23 \mathrm{~h}$ light and $1 \mathrm{~h}$ dark on days $0-7$, and a photoperiod of $20 \mathrm{~h}$ light and $4 \mathrm{~h}$ dark thereafter in accordance with the AA Broiler Management Guide [41]. The room temperature was maintained at $33-35^{\circ} \mathrm{C}$ on days $0-3$, at $32-34^{\circ} \mathrm{C}$ on days $4-7$ and gradually reduced to the maintenance temperature of $20^{\circ} \mathrm{C}$ by day 42 . The relative humidity was kept at $70 \%$ during the first week and thereafter at about $60 \%$.

\section{Sample collection and parameter determination of carcass and meat traits}

Three birds of each replicate (cage) of each group ( $n=3 \times$ $6 \times 2$ ) were selected randomly, weighed, electrically stunned, and manually slaughtered within $5 \mathrm{~min}$ [42]. The muscle of the middle part of left pectoralis was sampled and washed with PBS buffer $\left(\mathrm{NaCl} 8 \mathrm{~g} / \mathrm{L}, \mathrm{Na}_{2} \mathrm{HPO}_{4}\right.$ $\left.1.44 \mathrm{~g} / \mathrm{L}, \mathrm{KH}_{2} \mathrm{PO}_{4} 0.24 \mathrm{~g} / \mathrm{L}, \mathrm{KCl} 0.2 \mathrm{~g} / \mathrm{L}, \mathrm{pH} 7.2\right)$ to remove any blood and surface contaminants and immediately froze in liquid nitrogen and stored at $-80^{\circ} \mathrm{C}$ for molecular analysis including 2DIGE and qPCR validation.

The carcass traits of chicken fed E. faecium or not were evaluated. Another three birds were randomly selected from each replicate (cage) of each group $(n=3 \times$ $6 \times 2$ ). The percentage by weight of pectoral (breast) muscle, leg muscle (drumstick) and abdominal fat to live body weight was each determined. The entire pectoralis of birds were collected; the left for the measurement of water-holding capacity and the right for $\mathrm{pH}$ and meat colour determination. Water-holding capacity was determined as drip loss and weight loss after cooking [43]. In drip loss determination, approximately $30 \mathrm{~g}$ of regularshaped muscle (denoted as $\mathrm{W}_{45} \mathrm{~min}$ ) was hung in an inverted dixie cup within a zip-sealed plastic bag that was then filled with nitrogen to avoid oxidation, evaporation, 
and mutual extrusion. All bags were stored at $4^{\circ} \mathrm{C}$ for $24 \mathrm{~h}$ and the surface moisture of the fillets was then absorbed with filter paper and the fillets reweighed $\left(\mathrm{W}_{24 \mathrm{~h}}\right)$ [44,45]. Drip loss was calculated by the following equation:

$$
\text { Drip loss }=\left(\mathrm{W}_{45 \min }-\mathrm{W}_{24 \mathrm{~h}}\right) \times 100 \% / \mathrm{W}_{45 \mathrm{~min}} \text {. }
$$

Cooking loss was measured at $72 \mathrm{~h}$ post mortem as follows: about $20 \mathrm{~g}$ of regular-shaped muscle was removed from refrigerator $\left(4^{\circ} \mathrm{C}\right)$, and the surface moisture of the fillets was absorbed with filter paper. After 20-min heating in a zip-sealed plastic bag in a water bath at $80^{\circ} \mathrm{C}$, the meat was allowed to cool to ambient temperature, blotted dry and reweighed. The cooking loss was calculated as the percent weight loss [46].

The $\mathrm{pH}$ values of the pectoral muscle were measured at $45 \mathrm{~min}$ and $24 \mathrm{~h}$ post mortem at a depth of 2-cm using a portable $\mathrm{pH}$ meter (Testo 205, Testo AG, Lenzkirch, Germany) [47]. The $\mathrm{pH}$ meter was calibrated using buffer solutions $(\mathrm{pH}=4.0$ and $\mathrm{pH}=7.0)$ after every 50 observations [48].

The colour of the fleshiest part near the top of the right pectoral muscle was assessed at $45 \mathrm{~min}$ and $24 \mathrm{~h}$ post mortem with a spectrophotocolourimeter (Minolta CR-400, Konica Minolta Sensing, Osaka, Japan) using the CIELAB system. The instrument was calibrated with a white-and-black tile before analysis in agreement with the International Commission on Illumination [49].

All data were presented as means \pm SD $(n=18)$ and subjected to a one-way ANOVA procedure provided in SPSS16.0 software. Treatment difference was assumed to be statistically significant when $p \leq 0.05$ unless otherwise stated.

\section{Two-dimensional fluorescence difference gel electrophoresis (2-D DIGE)}

Total protein extraction of muscle was carried out as described previously with some modifications [50]. The pectoral muscle samples of three chicken from each replicate (cage) were combined as a biological replicate $(n=6 \times 2)$, homogenized by pestle in liquid nitrogen and dissolved in $1 \mathrm{~mL}$ of PBS buffer ( $\mathrm{pH}$ 7.0) containing EDTA-free protease inhibitor cocktail tablets (Roche). The proteins, insoluble in PBS, were extracted by lysis buffer (9 M urea, $2 \mathrm{M}$ thiourea, 4\% CHAPS and EDTA-free protease inhibitor cocktail tablets, $\mathrm{pH} 8.5$ ) and combined with the PBS soluble proteins. Trichloroacetic acid was added at the ratio of $1: 9$, followed by $10-\mathrm{min}$ incubation at $-20^{\circ} \mathrm{C}$. After centrifugation at $15,000 \times g$ and $4^{\circ} \mathrm{C}$ for $10 \mathrm{~min}$, the pellet was washed with cold acetone, incubated and re-centrifuged as described above. The pellet was washed three times, air dried, suspended in lysis buffer at the ratio of $1 \mathrm{mg}: 10 \mu \mathrm{L}$, and sonicated for $2 \mathrm{~min}$. The protein concentration of the supernatant was determined by the 2-D Quant Kit (GE Healthcare).

Three 2-D DIGE gels (technical replicates) of each biological replicate were run as described by Lu et al. [51] with some modifications. The $\mathrm{pH}$ of the protein solutions was adjusted to 8.5 with $50 \mathrm{mM} \mathrm{NaOH}$, and the concentration was adjusted to $5 \mathrm{mg} / \mathrm{mL}$ with lysis buffer. Equal amounts of protein from the control and treatment groups were pooled together as the internal standard. The proteins $(50 \mu \mathrm{g})$ from the control, the treatment and internal standard were then labeled individually with 400 pmol of Cy3, Cy5 and Cy2, respectively, on ice for $30 \mathrm{~min}$ in the dark and then quenched with $1 \mu \mathrm{L}$ of $10 \mathrm{mM}$ lysine on ice for another $10 \mathrm{~min}$. The Cy3- and Cy5-labeled proteins $(50 \mu \mathrm{g})$ were combined, and then mixed with $50 \mu \mathrm{g}$ of Cy2-labeled internal standard. An equal volume of $2 \times$ sample buffer (9 M urea, $2 \mathrm{M}$ thiourea, 4\% CHAPS, $130 \mathrm{mM}$ DTT, 1\% IPG buffer, $\mathrm{pH}$ 3.0-10.0) was then added to the sample, followed by the addition of rehydration buffer (8 M urea, 2\% CHAPS, 45 mM DTT, 0.5\% IPG buffer, and a trace amount of bromophenol blue, $\mathrm{pH}$ $3.0-10.0)$ to a total volume of $450 \mu \mathrm{L}$. Samples were applied to 24-cm, pH 3.0-10.0 IPG strips (Bio-Rad), and isoelectric focusing was performed using the IPGphor IEF system (GE Healthcare). The isoelectric focusing program was set as follows: $50 \mathrm{~V}$ for $14 \mathrm{~h}$, Grd $500 \mathrm{~V}$ for $30 \mathrm{~min}$, Step $500 \mathrm{~V}$ for $1 \mathrm{~h}$, Grd $1000 \mathrm{~V}$ for $30 \mathrm{~min}$, Step $1000 \mathrm{~V}$ for $1 \mathrm{~h}$, Grd $8000 \mathrm{~V}$ for $3 \mathrm{~h}$, and Step $8000 \mathrm{~V} 30000 \mathrm{Vh}$. The IPG strips on the concentrator were equilibrated in buffer A (375 mM Tris-HCl [pH 8.8], $6 \mathrm{M}$ urea, 29.3\% glycerol, $2 \%$ SDS, $1 \%$ DTT and a trace amount of bromophenol blue) for $15 \mathrm{~min}$ at room temperature and followed by equilibration with buffer B (375 mM Tris- $\mathrm{HCl}$ [pH 8.8], $6 \mathrm{M}$ urea, 29.3\% glycerol, 2\% SDS, $2.5 \%$ iodoacetamid and a trace amount of bromophenol blue) for another 15-min incubation at room temperature. Homogeneous polyacrylamide gels (12\%) were precast with low fluorescence glass plates using an Ettan DALT six-gel caster, and IPG strips were placed on top of it. Strips were overlaid with $0.5 \%$ Agarose-LE (Affymatrix, Santa Clara, CA, USA) in $1 \times$ running buffer containing bromphenol blue and were run for 14-16 h (2 W per gel, overnight) at $16^{\circ} \mathrm{C}$ in an Ettan DALT six electrophoresis system (GE Healthcare). All electrophoresis procedures were performed in dim light or in the dark. After the run was completed, the 2-D DIGE gels were scanned in situ using a Typhoon 9410 Variable Mode Imager (GE Healthcare) according to the manufacturer's instructions.

All gel images were analyzed by the DeCyder Differential Analysis Software (Version 7.0, GE Healthcare) according to the manufacturer's recommendation. Briefly, a DeCyder differential in-gel analysis (DIA) module was performed for image analysis between samples within the same gel, while a DeCyder biological variation analysis (BVA) module was 
performed for pairwise image analysis among multiple gels. Ratios of differentially expressed proteins were shown as fold changes between the pectoral muscle samples of treated and control groups. An increase of protein abundance in the treated group was expressed as a positive value while a negative value denoted a decrease in protein abundance. Protein spots were normalized using the corresponding spot on the pooled internal standard on every gel, and student's $t$-test on logged ratios were used to compare the average spot volume of all detectable protein pairs. Differential expressions were observed visually by using different colour channels for the treated and control groups.

\section{Identification of differentially expressed proteins}

The protein spots were excised from the gels and destained for $30 \mathrm{~min}$ in $100 \mu \mathrm{L}$ of acetonitrile (50\%) and $25 \mathrm{mM} \mathrm{NH}_{4} \mathrm{HCO}_{3}(\mathrm{pH} 8.0,50 \%)$ until the gel particles were transparent. The particles were then dehydrated for 10 min with acetonitrile (100\%), dried for $30 \mathrm{~min}$ using a Speed-Vac system, and digested for $1 \mathrm{~h}$ at $4^{\circ} \mathrm{C}$ in $10 \mu \mathrm{L}$ of trypsin solution $\left(10 \mathrm{ng} / \mu \mathrm{L}\right.$ in $\left.25 \mathrm{mM} \mathrm{NH}_{4} \mathrm{HCO}_{3}\right)$. After the removal of excess trypsin by pipette, the reaction was incubated at $37^{\circ} \mathrm{C}$ for $12 \mathrm{~h}$, followed by addition of $30 \mu \mathrm{L}$ of $5 \%(\mathrm{v} / \mathrm{v})$ TFA $\left(37^{\circ} \mathrm{C}, 1 \mathrm{~h}\right)$, and $30 \mu \mathrm{L}$ of $50 \%$ (v/v) acetonitrile containing 2.5\% TFA. After $1 \mathrm{~h}$ incubation at $30^{\circ} \mathrm{C}$, the supernatants were pooled and dried to $10 \mu \mathrm{L}$ using a vacuum concentration system.

The digested protein spots were identified by LC-ChipESI-QTOF-MS instrument (Q-TOF 6520, Agilent, Santa Clara, CA, USA) equipped with capillary pump (G1382A), nano pump (G2225A), autosampler (G1377D), and chip cube (G4240A). The LC-Chip used (Agilent) consisted of a Zorbax 300SB-C18 enrichment column (40 nL, $5 \mu \mathrm{m})$ and a Zorbax 300SB-C18 analytical column $(75 \mu \mathrm{m} \times 43 \mathrm{~mm}$, $5 \mu \mathrm{m})$. The loading flow rate was $4 \mu \mathrm{L} / \mathrm{min}$, and the loading mobile phase was $0.1 \%$ formic acid (solvent A). Elution was performed with a binary mixture of solvents A and B ( $0.1 \%$ formic acid in acetonitrile) as follows: solvent B of $3-8 \%$ for $1 \mathrm{~min}, 8-40 \%$ for $5 \mathrm{~min}, 40-85 \%$ for $1 \mathrm{~min}$, and $85 \%$ for $1 \mathrm{~min}$. The chip flow rate was $300 \mathrm{~nL} / \mathrm{min}$. The MS conditions were: positive ion mode, Vcap of $1900 \mathrm{~V}$, drying gas flow rate of $5 \mathrm{~L} / \mathrm{min}$, drying gas temperature of $350^{\circ} \mathrm{C}$, fragment voltage of $175 \mathrm{~V}$, skimmer voltage of $65 \mathrm{~V}$, and reference masses $\mathrm{m} / \mathrm{z}$ of 149.02332 and 1221.02332 . The digested samples were diluted in $20 \mu \mathrm{L}$ of $0.1 \%$ formic acid, centrifuged for $5 \mathrm{~min}$ at $10,000 \times g$, and $10 \mu \mathrm{L}$ of the supernatant was injected. The spectra were calibrated using the mass reference standards of purine and HP-0921 (121.050873 and 922.009798, respectively; Agilent). The tandem mass spectra were retrieved using the Mass Hunter software (VersionB.02.01, Agilent). Before the MS/ MS data search, a peak-list was generated by the Mascot Distiller software (Version 3.2.1.0, Matrix Science, Boston,
MA, USA). The MS/MS data were searched against Mascot 2.2 (Matrix Science) applied to NCBInr (released March 2011; 13,473,798 sequences) with the parameters of carbamidomethyl $(\mathrm{C})$ and oxidation $(\mathrm{M})$ as the fixed and variable modifications, respectively: taxonomy, all entries; enzyme, trypsin/P; missed cleavages, 1 ; peptide tolerance, $\pm 20 \mathrm{ppm}$, and MS/MS tolerance, $\pm 0.02 \mathrm{Da}$. When the identified peptides were matched to multiple members of a protein family or a protein appeared under the same name and accession number, the match was made in terms of the higher Mascot score, the putative function and the differential patterns of the protein spots on the 2-D DIGE gels. Protein identifications were accepted if they established a probability greater than $95 \%$ and contained at least 2 identified peptides having maximal peptide coverage (Additional file 2: Table S2).

\section{Bioinformatic analysis}

The ClueGo software with the Gene Ontology database (released June 2012) and Kyoto encyclopedia of genes and genomes (KEGG) database (released October 2012) was used to classify identified proteins into specific functional terms and metabolic pathways. The gene ontology analysis based on biological process and enrichment analysis was performed by the right-side hyper-geometric statistic test and its probability value was corrected by Bonferroni's method [52]. To understand the differential proteins enriched into biological pathway, it is analyzed by ClueGo plug-in of cytoscape software. Symbol ID number of 22 differential proteins was put in the software. Pathway enrichment analysis used the G. gallus database from the Kyoto encyclopedia of genes and genomes (KEGG) database by the right-side hyper-geometric statistic test and its probability value was corrected by Bonferroni's method.

A protein interaction network of the differentially regulated proteins was analyzed using the online database resource Search Tool for the Retrieval of Interacting Genes (STRING 9.1, http://string-db.org/) [53]. The protein regulation networks and protein interaction maps are in the Gallus gallus molecular network database. The network nodes are the proteins, and the edges represent the predicted functional associations. An edge may be drawn with up to seven differently coloured lines; these lines represent the existence of the seven types of evidence used in predicting the associations. The interactions between the imported proteins and all proteins stored in the database were then identified.

\section{Determination of differentially expressed proteins by quantitative real-time PCR (qPCR)}

Total RNA extraction and CDNA synthesis of the pectoral muscle of control and treatment groups were performed by using TRNzol- $\mathrm{A}^{+}$and Fast Quant RT Kit (with gDNase) (TIANGEN), according to the manufacturer's 
instructions. The quality and concentration of RNA were detected using agarose gel electrophoresis and a spectrophotometer (Ultrospec 2100 pro, GE Healthcare). Seventeen differentially expressed proteins from two major functional groups (Carbohydrate metabolism and energy production, Cytoskeleton) were chosen for qPCR analysis. Specific primers for target genes of the important proteins were designed using the primer BLAST of NCBI and nucleotide information in GenBank (Additional file 3: Table S3). The qPCR was conducted using the iCycler iQ5 system (Bio-Rad). The 20- $\mu \mathrm{L}$ PCR reaction system contained $1 \mu \mathrm{L}$ of $\mathrm{cDNA}, 0.5 \mu \mathrm{L}$ of each primer $(10 \mu \mathrm{M}), 10 \mu \mathrm{L}$ of Super Real PreMix (SYBR Green) (TIANGEN) and $8.2 \mu \mathrm{L}$ of water. The fold-change of differentially expressed proteins on mRNA level was calculated using the $\mathrm{IQ}^{\mathrm{TM}} 5$ software (Bio-Rad) with the $2^{-\Delta \Delta C t}$ method [54]. All operational program for qPCR strictly followed the MIQE [55].

\section{Results}

The broiler chickens grew normally throughout the experiment [50], as reported before dietary supplementation with $E$. faecium did not significantly promote the growth rate and feed intake of broilers. However, the feed conversion efficiency was improved.

\section{Carcass traits}

The weights of pectoral muscle, leg muscle and abdominal fat as a percentage of live body weight are presented in Figure 1. Significant differences were observed between the treatment and control groups on day $42(p<0.05)$. Broilers fed E. faecium showed improved carcass composition with relatively more pectoral and leg muscles and less abdominal fat.

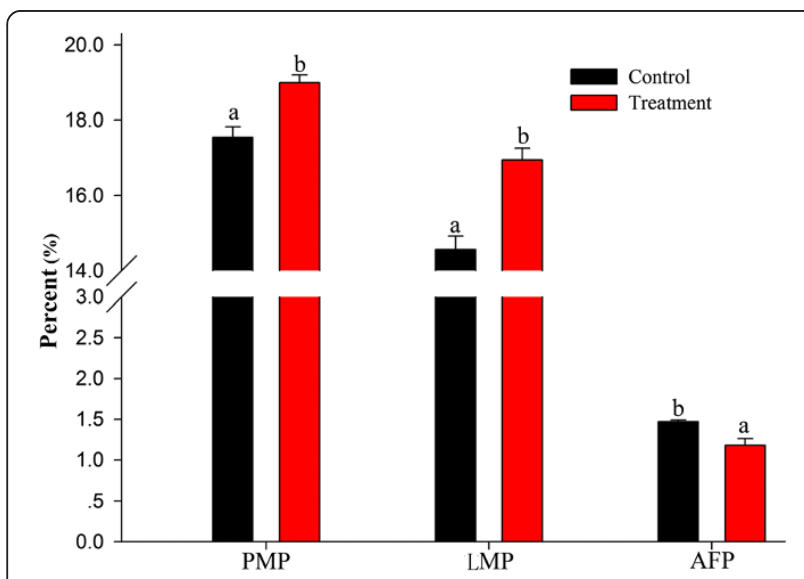

Figure 1 Effects of dietary E. faecium on the carcass quality of 42-day-old AA broilers. Different letters represent significant difference at $p<0.05$. PMP $=$ pectoral muscle weight/body weight, $\mathrm{LMP}=$ leg muscle weight (drumstick weight)/body weight, and AFP $=$ abdominal fat weight/body weight.

\section{Meat characteristics}

The effects of $E$. faecium supplementation on meat $\mathrm{pH}$ and colour are presented in Table 1 . At $45 \mathrm{~min}$ and $24 \mathrm{~h}$ post mortem, the $\mathrm{pH}$ values of the pectoral muscle of the treatment group were higher $(p<0.05)$ than that of the control group. The meat colour didn't change as much as meat $\mathrm{pH}$ value. At $45 \mathrm{~min}$ post mortem, only the lightness values showed significant difference $(p<0.05)$ between control and treatment, although the lightness, redness and yellowness values of the pectoral meat of the treatment group were numerically lower than those of the control group. Moreover, the treated broilers had the higher $\mathrm{pH}$ values and the darker and less yellow meat $(p<0.05)$. At $24 \mathrm{~h}$ post mortem, a significant difference was only observed in the yellowness value. The treated broilers had the higher $\mathrm{pH}$ values and the less yellow meat. However, no significant difference was detected in the meat redness and lightness in this study.

The pectoral muscle of broilers fed E. faecium had significantly less cooking loss and drip loss than the control birds (Figure 2). Moreover, a positive relationship was found between $\mathrm{pH}$ values and the water holding capacity of the muscles.

\section{Identification and comparison of differentially abundant proteins}

A total of 1631 protein spots were detected on 2-D DIGE gels of pectoral muscle. The molecular weights and $p \mathrm{I}$ values ranged from 10 to $100 \mathrm{kDa}$ and 3.0 to 10.0 , respectively (Figure 3 ). Abundant proteins, especially housekeeping protein $\beta$-actin were enriched in random sampling of spots on the gels very well. Moreover, the abundance of $\beta$-actin protein (spot 23) was not differentially expressed between control and treatment groups ( $p>0.05$, Figure 3 , Table 2) indicating the

Table 1 Effects of the dietary probiotic E. faecium on the pH and colour of pectoral muscles of 42-day-old AA broiler chickens (mean \pm S.D.)*

\begin{tabular}{lllc}
\hline Index & Control & E. faecium & $\boldsymbol{p}$ value \\
\hline $\mathrm{pH}$ at 45 min post mortem & $6.15 \pm 0.26^{\mathrm{a}}$ & $6.57 \pm 0.17^{\mathrm{b}}$ & 0.018 \\
$\mathrm{pH}$ at 24 h post mortem & $5.77 \pm 0.10^{\mathrm{a}}$ & $6.11 \pm 0.13^{\mathrm{b}}$ & 0.008
\end{tabular}

Meat colour at 45 min post mortem

$\begin{array}{lrrr}\text { Lightness } & 45.56 \pm 0.28^{\mathrm{a}} & 43.61 \pm 0.52^{\mathrm{b}} & 0.002 \\ \text { Redness } & 1.75 \pm 0.23^{\mathrm{a}} & 1.47 \pm 0.11^{\mathrm{a}} & 0.117 \\ \text { Yellowness } & 5.08 \pm 0.44^{\mathrm{a}} & 4.55 \pm 0.10^{\mathrm{a}} & 0.096\end{array}$

Meat colour at $24 \mathrm{~h}$ post mortem

\begin{tabular}{lccc} 
Lightness & $49.29 \pm 1.29^{\mathrm{a}}$ & $48.60 \pm 0.28^{\mathrm{a}}$ & 0.248 \\
Redness & $1.20 \pm 0.07^{\mathrm{a}}$ & $1.21 \pm 0.37^{\mathrm{a}}$ & 0.959 \\
Yellowness & $5.72 \pm 0.17^{\mathrm{a}}$ & $4.18 \pm 0.21^{\mathrm{b}}$ & 0.001 \\
\hline
\end{tabular}

*Data of the same row with different letters ( $a$ or b) are significantly different at $\mathrm{p}<0.05$. 


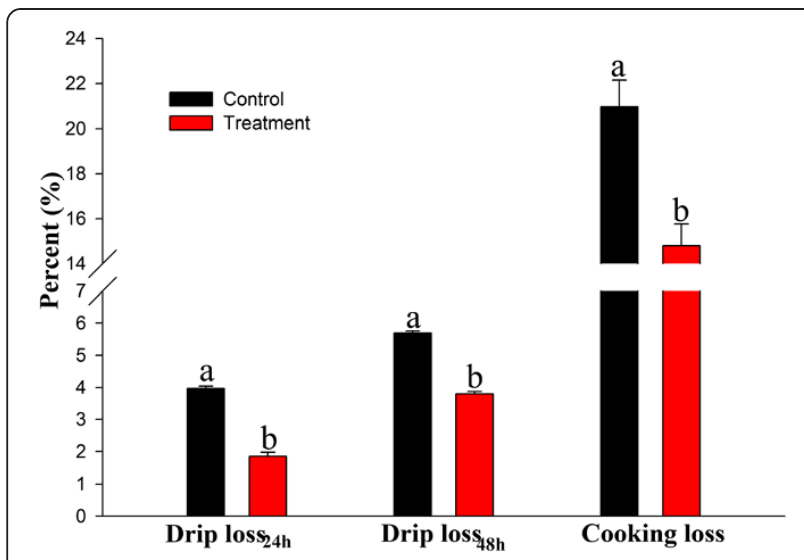

Figure 2 Effects of dietary E. faecium on the water holding capacity of the pectoral muscles of 42 -day-old AA broilers. Different letters represent significant difference at $p<0.05$.

reproducibility of the experiment is convincible. The most significant changes $(1.5$-fold, $p<0.05)$ between control and treatment groups were selected for protein identification by LC-Chip-ESI-QTOF-MS. Except for unidentified proteins due to weak spectra, 22 altered spots were identified (Table 2). These proteins were grouped into four categories based on biological functions: carbohydrate and energy metabolism (50\%), cytoskeleton (41\%), chaperone protein (4.5\%) and transporter (4.5\%) (Figure 4). Those related to carbohydrate and energy metabolism and cytoskeleton were predominant and accounted for approximately $90 \%$ of the differential abundance proteins identified.

A comparison of proteins of differential abundance showed that more protein species were up-regulated in chickens fed E. faecium (16 of 22) (Figure 5). Of the 16 up-regulated protein species, nine proteins were involved in carbohydrate metabolism, five in cytoskeleton, one in chaperone protein and one in transporter. The four of six down-regulated proteins in chickens fed $E$. faecium were mainly related to cytoskeleton.

Bioinformatics analysis of proteins of differential abundance GO annotation and KEGG pathway enrichment analysis were used to determine the biological characterization and statistical significance of the proteomics data of the pectoral muscle. The ClueGo software identified three highly over represented functional groups (Figure 6), including carbohydrate metabolism, catabolism and anabolism processes. Glucose metabolic processes (metabolism, glycolysis and gluconeogenesis) were the leading terms (a term with statistical significance or with lowest $p$ value), respectively. When glucose metabolic process was used as the leading term, PGM1 (spot 7, up-regulated), LDHA (spot 12, up-regulated), PKM2 (spot 14, down-regulated), FBP2 (spot 17, up-regulated), GAPDH (spot 19, up-

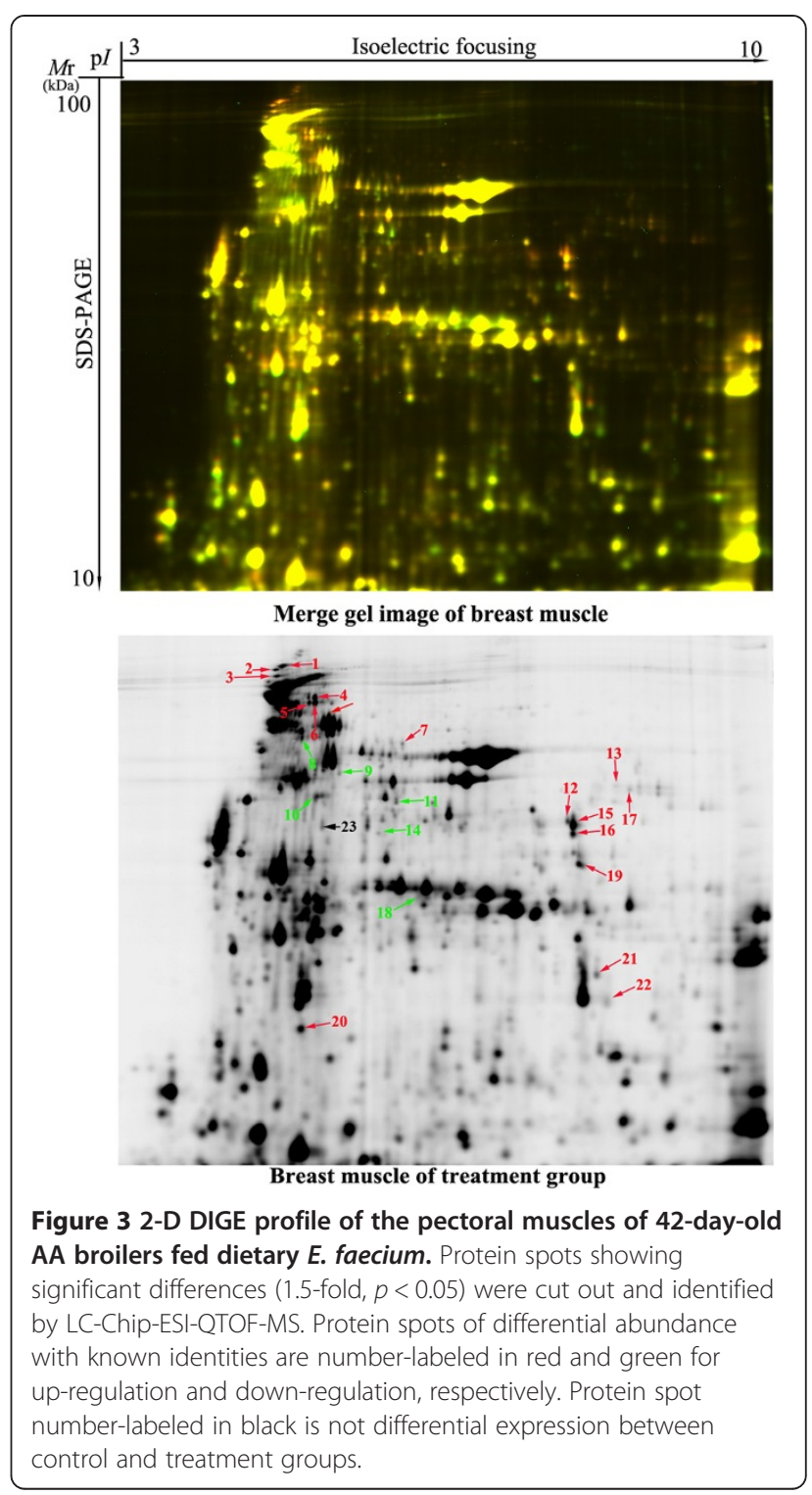

regulated) and PGK (spot 20, up-regulated) were found to be enriched. When glycolysis process was used as the leading term, LDHA (spot 12, up-regulated), PKM2 (spots 14, down-regulated), GAPDH (spot 19, up-regulated) and PGK (spots 20, up-regulated), were found to be enriched. With gluconeogenesis as the leading term, FBP2 (spot 17, up-regulated) and GAPDH (spot 19, up-regulated) were enriched. This functional enrichment analysis indicated that the E. faecium supplement had effects on the anabolism and catabolism of carbohydrate in pectoral muscle of broilers.

The biological pathway is a real functional unit in living systems. Pathway enrichment analysis can help identify key pathways for biological processes. KEGG pathway enrichment analysis of the differential proteins revealed that 14 differentially expressed proteins were significantly enriched in the four pathways (Table 3). These proteins 
Table 2 Differential proteins classified by biological process in the pectoral muscles of 42-day-old AA broiler chickens fed the dietary probiotic $E$. faecium ${ }^{a}$

\begin{tabular}{|c|c|c|c|c|c|c|c|c|c|}
\hline Spot no. & Protein name & $\begin{array}{l}\text { Accession } \\
\text { no. }\end{array}$ & $\begin{array}{l}\text { Symbol } \\
\text { ID }\end{array}$ & $M r(\mathrm{kDa}) / \mathrm{pl}$ & $\begin{array}{c}\text { Sequence } \\
\text { coverage (\%) }\end{array}$ & Matched & $\begin{array}{l}\text { Mascot } \\
\text { score }\end{array}$ & $\begin{array}{l}\text { Av. } \\
\text { ratio }\end{array}$ & $p$ value \\
\hline \multicolumn{10}{|c|}{ Carbohydrate and energy metabolism } \\
\hline 7 & $\begin{array}{l}\text { Phosphoglucomutase-1 } \\
(\mathrm{EC}=5.4 .2 .2)\end{array}$ & gi|84619526 & PGM1 & $67.063 / 8.98$ & 40 & 49 & 851 & 1.7 & $2.60 \mathrm{E}-04$ \\
\hline 12 & $\begin{array}{l}\text { L-lactate dehydrogenase A chain } \\
(E C=1.1 .1 .27)\end{array}$ & gi|45384208 & LDHA & $36.776 / 7.75$ & 48 & 30 & 542 & 1.7 & $2.40 \mathrm{E}-03$ \\
\hline 13 & $\begin{array}{l}\text { Mitochondrial creatine kinase } \\
(E C=2.7 .3 .2)\end{array}$ & gi|268370038 & CKMT2 & $45.851 / 8.72$ & 28 & 10 & 169 & 2.0 & $4.20 E-03$ \\
\hline 14 & $\begin{array}{l}\text { Pyruvate kinase muscle isozyme } \\
(\mathrm{EC}=2.7 .1 .40)\end{array}$ & gi|45382651 & PKM2 & $58.434 / 7.29$ & 18 & 22 & 206 & -1.5 & 1.70E - 04 \\
\hline 15 & $\begin{array}{l}\text { Creatine kinase M-type } \\
(E C=2.7 .3 .2)\end{array}$ & gi|45382875 & CKM & $43.529 / 6.50$ & 16 & 16 & 75 & 1.8 & $1.90 \mathrm{E}-04$ \\
\hline 17 & $\begin{array}{l}\text { Fructose-1,6-bisphosphatase } 2 \\
(\mathrm{EC}=3.1 .3 .11)\end{array}$ & gi|50762391 & FBP2 & $37.364 / 8.09$ & 35 & 25 & 621 & 1.7 & $2.60 E-03$ \\
\hline 18 & $\beta$-Enolase $(E C=4.2 .1 .11)$ & gi|46048765 & ENO3 & $47.566 / 7.28$ & 21 & 22 & 352 & -1.5 & $2.20 \mathrm{E}-02$ \\
\hline 19 & $\begin{array}{l}\text { Glyceraldehyde-3-phosphate } \\
\text { dehydrogenase }(E C=1.2 .1 .12)\end{array}$ & gi|46048961 & GAPDH & $35.989 / 8.71$ & 46 & 38 & 557 & 1.6 & $2.10 E-03$ \\
\hline 20 & $\begin{array}{l}\text { Phosphoglycerate kinase } \\
(E C=2.7 .2 .3)\end{array}$ & gi|45384486 & PGK & $45.087 / 8.31$ & 10 & 43 & 94 & 1.5 & $1.80 \mathrm{E}-02$ \\
\hline 21 & $\begin{array}{l}\text { Phosphoglycerate mutase } 1 \\
(E C=3.1 .3 .13)\end{array}$ & gi|71895985 & PGAM1 & $29.051 / 7.03$ & 37 & 9 & 120 & 1.7 & $5.70 E-03$ \\
\hline 22 & $\begin{array}{l}\text { Creatine kinase M-type } \\
(E C=2.7 .3 .2)\end{array}$ & gi|45382875 & CKM & $43.529 / 6.50$ & 15 & 5 & 103 & 1.9 & $1.50 E-02$ \\
\hline \multicolumn{10}{|c|}{ Cytoskeleton } \\
\hline 1 & Myosin-3 & gi|165973976 & MYH3 & $223.88 / 5.65$ & 19 & 59 & 1481 & 1.9 & $7.10 E-03$ \\
\hline 2 & Myosin, heavy chain 1 & gi|61657934 & $\mathrm{MYH1}$ & $223.746 / 5.61$ & 12 & 41 & 1209 & 1.8 & $1.40 \mathrm{E}-03$ \\
\hline 3 & $\begin{array}{l}\text { Myosin, heavy chain 2, } \\
\text { skeletal muscle }\end{array}$ & gi|45383668 & $\mathrm{MYH} 2$ & $223.716 / 5.71$ & 14 & 39 & 1039 & 2.0 & $6.80 E-04$ \\
\hline 5 & a-Actinin-2 & gi|46048687 & ACTN2 & $104.779 / 5.26$ & 65 & 63 & 472 & 1.9 & $3.40 \mathrm{E}-04$ \\
\hline 8 & Myosin, heavy chain 6 & gi|61657939 & MYH6 & $223.976 / 5.63$ & 16 & 62 & 1288 & -1.6 & $3.30 E-03$ \\
\hline 9 & Myosin, heavy chain 7B, beta & gi|45383005 & SSMHC & $88.521 / 5.33$ & 3 & 8 & 66 & -1.8 & $1.40 \mathrm{E}-03$ \\
\hline 10 & Myosin, heavy chain 15 & gi|45382109 & MYH15 & $223.804 / 5.61$ & 2 & 13 & 88 & -1.6 & $1.00 E-02$ \\
\hline 11 & Slow myosin heavy chain 1 & gi|363746193 & SM1 & $31.625 / 5.83$ & 20 & 43 & 170 & -1.5 & $4.00 E-04$ \\
\hline 16 & Structural muscle protein titin & gi|363735918 & TTN & $243.174 / 6.97$ & 8 & 25 & 424 & 1.8 & $1.60 E-03$ \\
\hline \multicolumn{10}{|c|}{ Chaperone protein } \\
\hline 4 & Heat shock $70 \mathrm{kDa}$ protein & gi|55742654 & HSP70 & $70.098 / 5.66$ & 23 & 33 & 798 & 1.5 & $7.70 E-04$ \\
\hline \multicolumn{10}{|c|}{ Transporter } \\
\hline 6 & Albumin & gi|45383974 & ALB & $71.868 / 5.51$ & 62 & 59 & 1481 & 2.1 & $2.70 E-05$ \\
\hline \multicolumn{10}{|c|}{ Housekeeping protein } \\
\hline 23 & $\beta$-actin & gi|45382927 & ACTB & $8.315 / 9.25$ & 46 & 46 & 213 & 1.01 & $1.90 \mathrm{E}-01$ \\
\hline
\end{tabular}

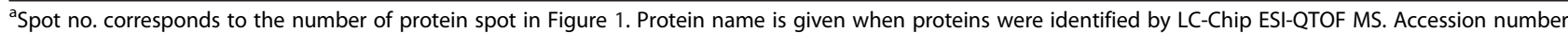
is the unique number given to mark the entry of a protein in the database NCBInr. Theoretical molecular weight (Mr) and isoelectric point ( $\mathrm{p} /$ ) of the identified proteins are retrieved from the protein database of NCBInr. Sequence coverage is the ratio of the number of amino acids in every peptide that matches with the mass spectrum divided by the total number of amino acids in the protein sequence. Matched peptide is the number of paring an experimental fragmentation spectrum to a theoretical segment of protein and searched peptide is the total searched peptide. Mascot score is searched against the database NCBInr. Av. ratio and $p$ value are calculated using DeCyder software version 7.0. Av. ratio is the rate of expression abundance of protein in the treatment muscle and the control muscle.

were involved in glycolysis/gluconeogenesis, pentose phosphate pathway, pyruvate metabolism, and tight junction. These results indicated these proteins play the significant role in the improvement of meat quality after feeding E. faecium and only very few pathways are induced. 


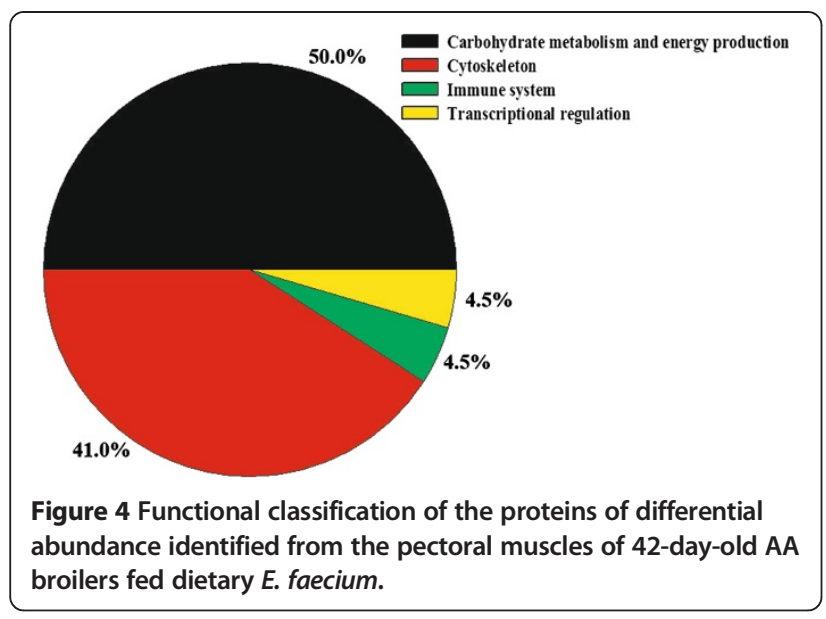

Protein networks may provide insights into the biological process involving several proteins. Using the online tools of STRING 9.1, 17 proteins acted as key nodes with various relationships in biological interaction networks (BIN) (Figure 7). Eight proteins (47.1\%) were related to

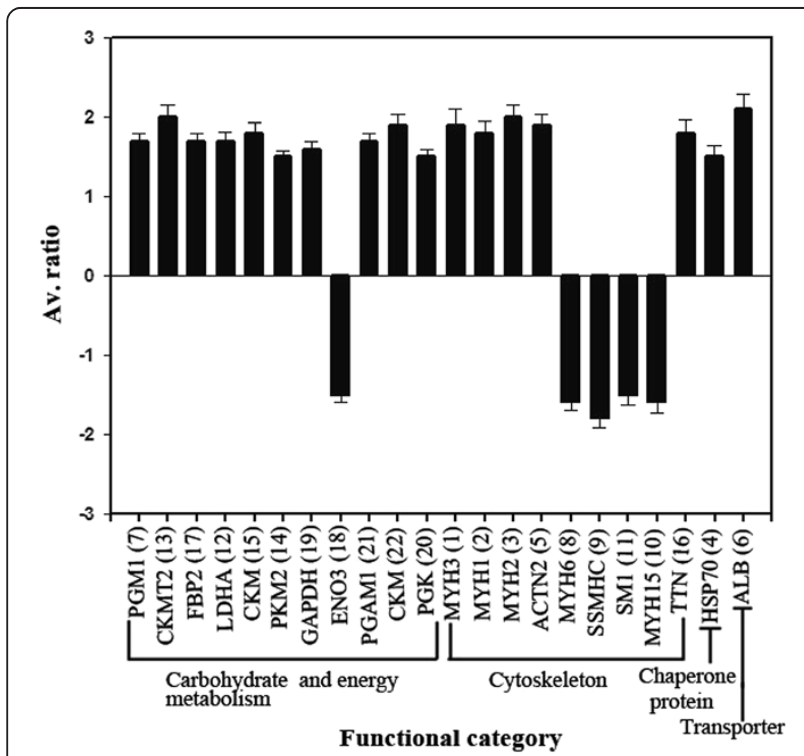

Figure 5 Quantitative comparisons of the proteins of differential abundance from the pectoral muscles of 42-day-old AA broilers fed dietary E. faecium. Av. ratio is the ratio of protein abundance of the treatment compared to the control groups. Positive values indicate the high protein abundance of the treatment group. PGM1, phosphoglucomutase-1; LDHA, L-lactate dehydrogenase A chain; CKMT2, mitochondrial creatine kinase; CKM, creatine kinase M-type; FBP2, fructose-1,6-bisphosphatase 2; GAPDH, glyceraldehyde-3phosphate dehydrogenase; PGK, phosphoglycerate kinase; PGAM1, phosphoglycerate mutase 1; ENO3, $\beta$-enolase; PKM2, pyruvate kinase muscle isozyme; $\mathrm{MYH1}$, myosin, heavy chain $1 ; \mathrm{MYH} 2$, myosin, heavy chain 2; MYH3, myosin-3; MYH6, myosin, heavy chain 6; MYH15, myosin, heavy chain 15; SSMHC, myosin, heavy chain 7B, beta; ACTN2, a-actinin-2; TTN, structural muscle protein titin; SM1, slow myosin heavy chain 1; HSP70, heat shock $70 \mathrm{kDa}$ protein; ALB, albumin. carbohydrate and energy metabolism, seven to cytoskeleton, one to chaperone and one to transporter. The results indicate that four main clusters could be individuated in the interaction map and summarized into significant interactions with the other proteins in the map. Of these, PKM2, GAPDH, PGK, LDHA and PGAM1 were the highest degree nodes.

\section{Test gene expression of differential expressed proteins}

The correlation between mRNA expression levels and protein abundances depends on several biological factors, such as translation efficiency and protein half-life. Therefore, to manipulate meat quality at gene level, it is important to determine the mRNA expression that regulates meat quality at a protein level. Based on the KEGG pathway and GO analysis of the differentially regulated proteins, seven proteins, i. e. GAPDH, LDHA, PGK1, PKM2, FBP2, CKMT2 and ENO3, were identified as potentially important regulators of meat quality. Further qPCR analysis of these proteins at the mRNA level (Figure 8) demonstrated their roles in glycolysis. The abundance of LDHA, PGK1, FBP2 and CKMT2 were consistent with their mRNA expression levels. However, the mRNA and protein levels of GAPDH, PKM2 and ENO3 were inconsistent. This inconsistency may reflect the unsynchronized abundances of mRNA and proteins.

\section{Discussion}

The ban of antibiotics as growth promoters has increased the search for alternative feed additives for poultry production. Probiotics are one promising alternative due to their positive effects on broiler growth performance, including carcass traits and meat quality $[14,33]$. Our data reveals that the probiotic organism $E$. faecium increases the carcass percentage of both pectoral and leg muscles and reduces abdominal fat percent. This result is in agreement with previous results that broiler chickens fed E. faecium had significantly less abdominal fat $[33,56]$. The meat quality of the pectoral muscle was also improved in terms of $\mathrm{pH}$, colour, and water-holding capacity by feeding the probiotic which triggered the differential expression of 22 proteins. These proteins are involved in carbohydrate metabolism, cytoskeleton, chaperone and transportation. Of the 22 proteins, the 17 linked in the BIN are mainly involved in carbohydrate and energy metabolism and tight junction pathways, suggesting roles in the regulation of meat quality improvement. In combination with our previous studies [50], the main probiotic effects of $E$. faecium occur in the intestine by improving intestinal microbiota composition and mucosa ultrastructure, enhancing nutrient absorption and reducing energy consumption. Our unpublished liver proteome data of broilers fed E. faecium identified differentially expressed proteins related to substrate metabolism, and the 


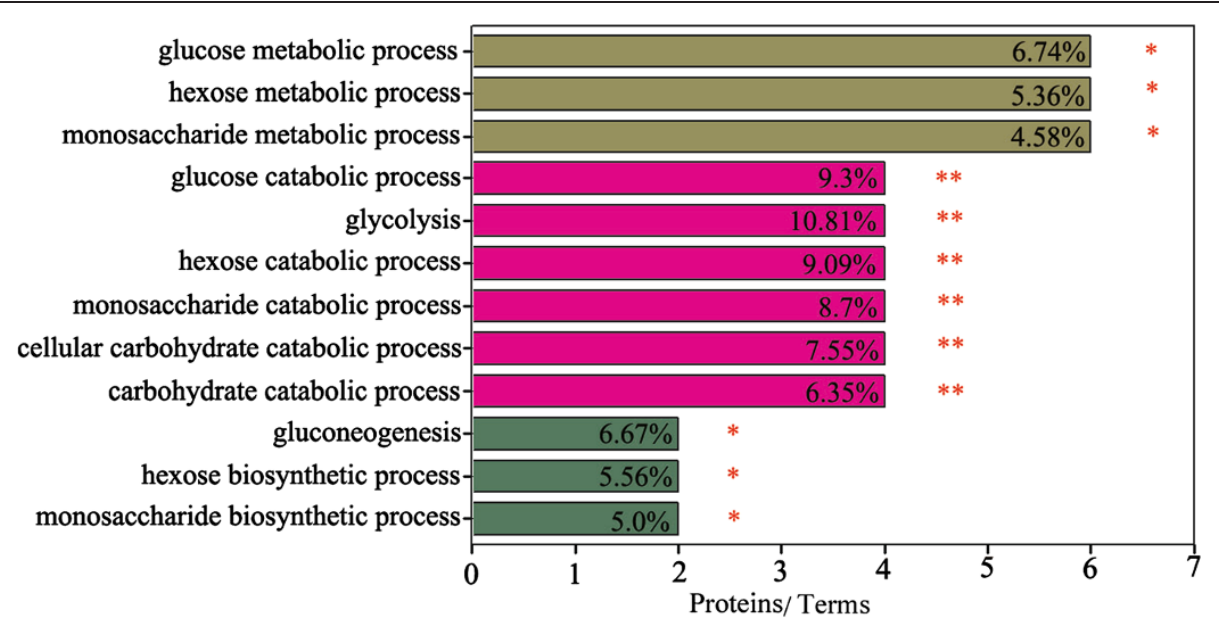

Figure 6 Functional enrichment analysis of differential abundance of proteins from the pectoral muscles of 42-day-old AA broilers fed dietary E. faecium using the ClueGO software. * and ${ }^{* *}$ indicate significant enrichment at $p<0.05$ and $p<0.01$, respectively.

antioxidant, and immune systems. These differential proteins changed the pentose phosphate and citric acid pathways, enhanced the anabolic metabolism of amino acids and improved antioxidant and immune capacity. As a result, the physio-biochemical indexes of muscle $(\mathrm{pH}$, colour, and drip loss) are improved.

Conversion of muscle to meat is regulated by complex physicochemical processes during post mortem storage [57]. These processes determine subsequent meat quality [58]. In live broilers, aerobic oxidation and glycolysis are important pathways for the provision of energy for muscle contraction and growth. After slaughter, the internal supply of oxygen rapidly diminishes and aerobic respiration ceases after cessation of blood circulation. Anaerobic respiration upregulates immediately, as glycolysis becomes the only pathway in muscle generating energy [59]. Post mortem glycolysis results in an accumulation of lactate and a decline in muscle $\mathrm{pH}$. The reduced $\mathrm{pH}$ changes the activity of enzymes. This was reflected in our data (see Table 2) as the expression of a number of enzymes changed in the pectoral muscle after E. faecium supplementation as indicated by up-regulation of eight proteins: phosphoglucomutase-1 (PGM1, spot 7), mitochondrial creatine kinase (CKMT2, spot 13), creatine kinase M-type (CKM, spots 15 and 22), fructose-1,6-bisphosphatase (FBP2, spot 17), L-lactate dehydrogenase A chain (LDHA, spot 12), glyceraldehyde-3-phosphate dehydrogenase (GAPDH, spot 19), phosphoglycerate mutase 1 (PGAM1, spot 21), and phosphoglycerate kinase (PGK, spot 20).

Phosphoglucomutase catalyses the conversion of glucose 1-phosphate and glucose 6-phosphate in glycogenesis [60]. Fructose 1,6-bisphosphatase mainly converts fructose 1,6bisphosphate to fructose 6-phosphate in gluconeogenesis and reductive the pentose phosphate cycle $[61,62]$. Therefore, up-regulation of phosphoglucomutase-1 (PGM1, spot 7) and fructose 1,6-bisphosphatase (FBP2, spot 17) in the pectoral muscle indicates improved storage of energy substrates. Moreover, energy production by glycolysis plays a vital role in the contraction and movement of muscles [63]. Significant up-regulation of glycolytic enzymes such as LDHA, PGAM1, CKM, GAPDH and PGK were observed in the pectoral muscle of broilers fed E. faecium. CKM is involved in the creatine/phosphocreatine shuttle. Increased expression of CKM suggests that meat

Table 3 Enriched KEGG pathway-based sets of differential proteins in the pectoral muscles of 42-day-old AA broiler chickens fed dietary probiotic E. faecium ${ }^{a}$

\begin{tabular}{|c|c|c|c|c|}
\hline Pathway name & Count & Proteins & $p$ value & $q$ value \\
\hline Glycolysis/Gluconeogenesis & 7 & $\begin{array}{l}\text { PGM1 (spot 7), LDHA (spot 12), PKM2 (spot 14), } \\
\text { FBP2 (spot 17), GAPDH (spot 19), PGK1 (spot 20), } \\
\text { and PGAM1 (spot 21) }\end{array}$ & $5.03 E-10$ & $2.51 E-09$ \\
\hline Pentose phosphate pathway & 2 & PGM1 (spot 7) and FBP2 (spot 17) & $3.70 E-03$ & $1.85 E-02$ \\
\hline Pyruvate metabolism & 2 & LDHA (spot 12) and PKM2 (spot 14) & $1.07 \mathrm{E}-02$ & $5.34 \mathrm{E}-02$ \\
\hline Tight junction & 7 & $\begin{array}{l}\text { MYH3 (spot 1), MYH1 (spot 2), MYH9 (spot 3), } \\
\text { ACTN2 (spot 5), MYH6 (spot 8), MYH7B (spot 9), } \\
\text { and MYH15 (spot 10) }\end{array}$ & $2.97 \mathrm{E}-07$ & $1.49 E-06$ \\
\hline
\end{tabular}

${ }^{a}$ The number of count refers to the amount of proteins involved in the pathway. $p$ values are calculated according to a hypergeometric test, $q$ values represent $p$ values corrected for multiple testing using the false discovery rate method. 


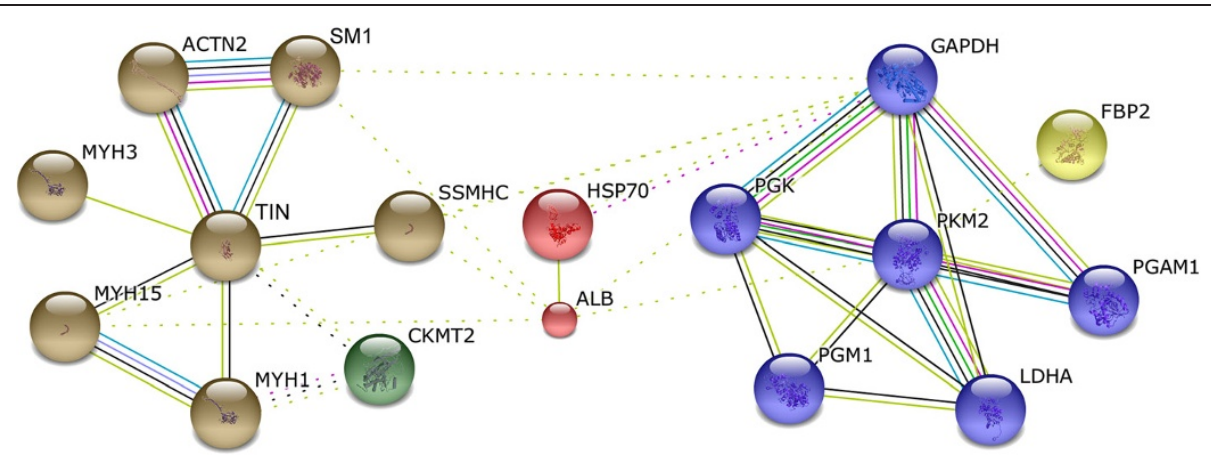

Figure 7 Biological interaction network of the proteins of differential abundance from the pectoral muscles of 42-day-old AA broilers fed dietary E. faecium. Lines between proteins indicate evidence of association. Red indicates fusion, green indicates neighborhood, blue indicates co-occurrence, purple indicates experimental evidence, yellow indicates text-mining evidence, light blue indicates database evidence, and black indicates coexpression. MYH1, myosin, heavy chain 1; MYH3, myosin-3; MYH15, myosin heavy chain 15; SSMHC, myosin, heavy chain 7B, beta; ACTN2, a-actinin-2; TTN, structural muscle protein titin; SM1, slow myosin heavy chain 1; PGM1, phosphoglucomutase-1; LDHA, L-lactate dehydrogenase A chain; CKMT2, mitochondrial creatine kinase; FBP2, fructose-1,6-bisphosphatase 2; GAPDH, glyceraldehyde-3-phosphate dehydrogenase; PGK, phosphoglycerate kinase; PGAM1, phosphoglycerate mutase 1; PKM2, pyruvate kinase muscle isozyme; HSP70, heat shock $70 \mathrm{kDa}$ protein; and ALB, albumin.

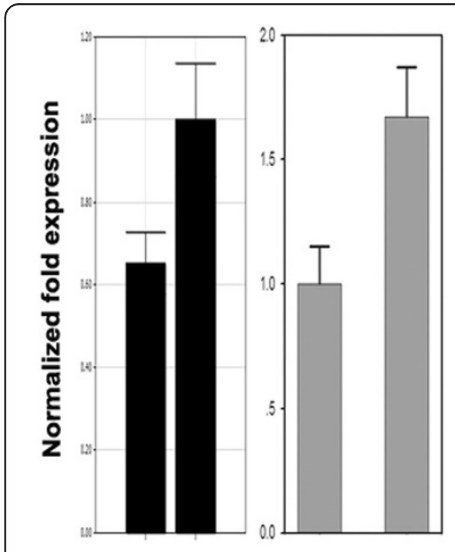

Control Treatment Control Treatment FBP2 (spot 17)
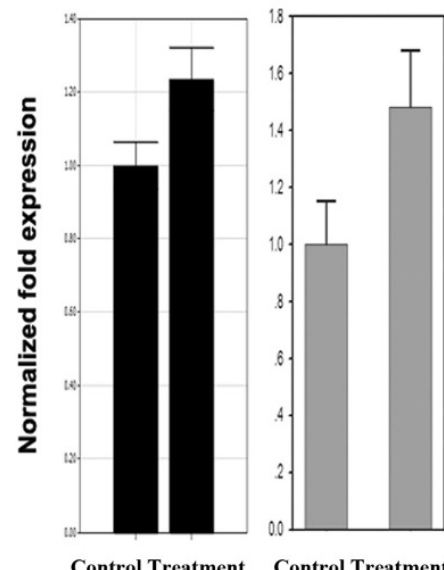

PGK (spot 20)

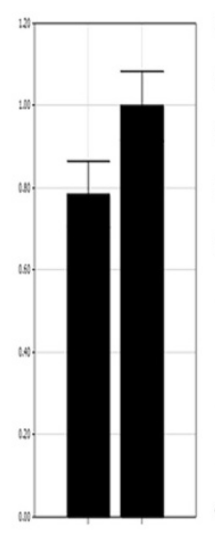

Control Treatment ENO3 (spot 18)

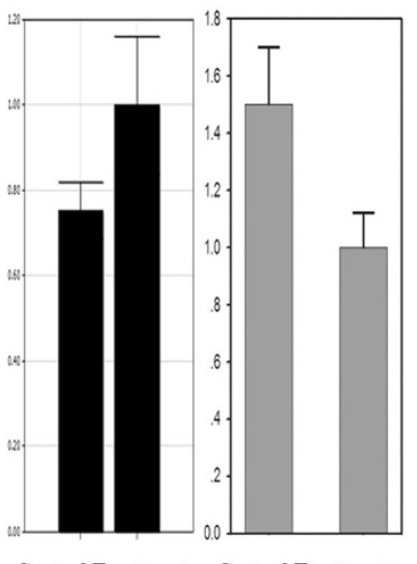

PKM2 (spot 14)

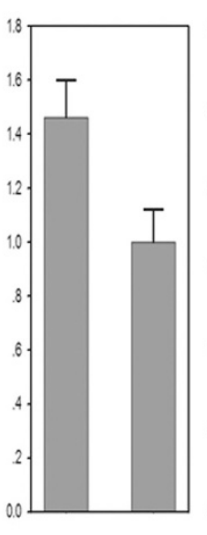

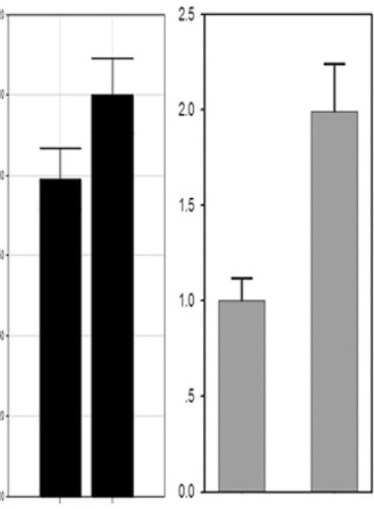

Control Treatment Control Treatment CKMT2 (spot 13)

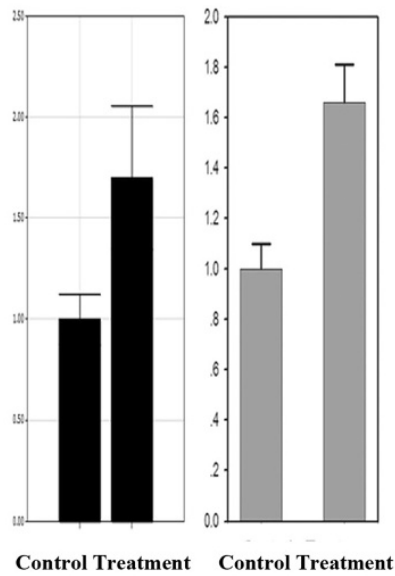

LDHA (spot 12)

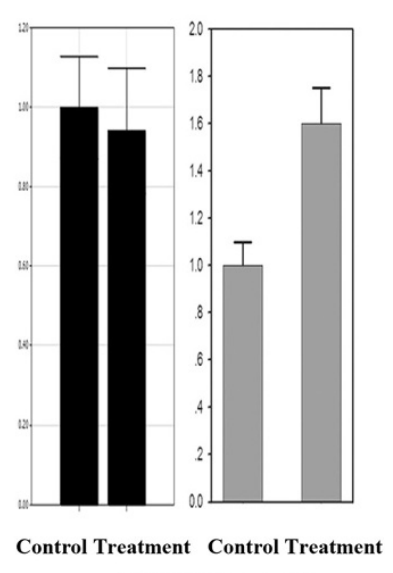

GAPDH (spot 19)

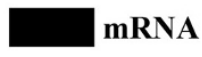

Protein

Figure 8 Validation using qPCR of seven proteins of differential abundance from the pectoral muscles of 42 -day-old AA broilers fed dietary E. faecium at the mRNA level. Samples were normalized with the reference gene 28S rDNA. FBP2, fructose-1,6-bisphosphatase 2; GAPDH, glyceraldehyde-3-phosphate dehydrogenase; ENO3, $\beta$-enolase; LDHA, L-lactate dehydrogenase A chain; CKMT2, mitochondrial creatine kinase; PGK, phosphoglycerate kinase; PKM2, pyruvate kinase muscle isozyme. 
tenderness is increased as a result in the delay of post mortem glycolytic activity due to greater reservoirs of phosphocreatine. Higher CKM levels also indicate that ATP stored in muscle cells is depleted slower and sarcomere contraction is delayed. This process also increases meat tenderness [64]. In addition, GAPDH and CKM have been reported to be related to myofibril degradation and produce tender meat [65]. Increases in the expression of GAPDH and CKM also occurred in broiler chickens fed E. faecium of our experiment.

The contribution of metabolic enzymes to meat traits is complex [66]. Enolase catalyzes 2-phosphoglycerate to phosphoenolpyruvate during glycolysis [67] and pyruvate kinase catalyzes the transfer of a phosphate group from phosphoenolpyruvate to adenosine diphosphate (ADP) in the aerobic glycolysis pathway, yielding pyruvate and adenosine triphosphate (ATP). Pyruvate will be converted into lactic acid by lactic dehydrogenase. In the present study, down-regulation of $\beta$-enolase (ENO3, spot 18) and pyruvate kinase muscle isozyme (PKM2, spot 14) in broilers fed E. faecium would reduce the conversion of 2-phosphoglycerate to pyruvic acid. This would reduce the level of lactic acid and increase $\mathrm{pH}$ in the pectoral muscle. It has been reported that meat with a higher $\mathrm{pH}$ has higher water holding capacity [68]. Thus, the increased $\mathrm{pH}$ and water holding capacity of muscle from broilers fed $E$. faecium is likely related to downregulated expression of $\beta$-enolase and pyruvate kinase muscle isozyme.

The second main physiochemical change after slaughter is the transformation of phosphocreatine $(\mathrm{PCr})$ to creatine and hydrolysis of ATP [69]. The up-regulated creatine kinase (CKMT2, spot 13; CKM, spots 15 and 22) in the muscle of broilers fed E. faecium enhanced the accumulation of $\mathrm{PCr}$ and production of ATP because creatine kinase participates in the interconversion of creatine and ATP to create phosphocreatine (PCr) and ADP [70]. Furthermore, ATP splitting in the muscle in situ post mortem can increase the water holding capacity of muscles. This result is consistent with previous findings in Casertana pigs [71]. In the present study, higher CKM levels in the muscle of broilers fed E. faecium increased muscle moisture content. The normal functionality of bird muscle are usually associated with myofibrillar structure, such as actin, myosin, cofilin, destrin, titin and tubulin [72]. Degradation of cytoskeletal proteins to smaller peptides weakens the myofibrillar lattice and influences meat quality, especially meat tenderness and water holding capacity [73-77]. Calpains degrade muscle proteins faster at higher tissue $\mathrm{pH}[78,79]$. Moreover, degradation of key myofibrillar proteins increases water holding capacity [68]. In this study, the higher $\mathrm{pH}$ values in the broilers supplemented with $E$. faecium was associated with degradation of structural proteins and improvement in water holding capacity. As the meat $\mathrm{pH}$ value was higher than the $p$ I values of myofibrillar proteins, this can also increase the binding of water molecules. More light would be absorbed by these water molecules in the muscle, resulting in a darker meat [80]. In our results, the muscle of broilers with $E$. faecium supplementation had higher water-holding capacity and lower lightness and yellowness in colour were in agreement with previous studies $[48,81,82]$. In addition, a negative correlation between lightness of meat colour and $\mathrm{pH}$ and a positive correlation between meat redness and $\mathrm{pH}$ have been observed $[7,48,82,83]$. Similar relationships were observed in this experiment. These changes in meat characteristics were the consequences of cytoskeletal protein degradation and $\mathrm{pH}$ changes when glycolysis stopped.

Chaperon functions are important for post mortem muscle changes [84]. Chaperon proteins such as HSPs are correlated with meat tenderness $[66,85,86]$. These proteins are involved in folding of newly or denatured proteins $[87,88]$ and promote the recovery of cell membranes, thus maintaining cell homeostasis $[89,90]$. Therefore, the up-regulation of HSP70 (spot 4) in broiler muscle fed E. faecium was potentially useful for maintaining muscle cell integrity and repairing denatured proteins, such as desmin and sarcoplasmic proteins. This would be related to the improvement of meat colour and water-holding capacity [91]. It has been reported that desmin, a cytoskeletal protein, is a marker protein for water-holding capacity since higher desmin levels in pig muscle correspond to lower drip loss [92]. Moreover, up-regulation of GAPDH and HSP70 is related to meat tenderness, this result is in agreement with the findings in pigs [71,93]. Therefore, the enhanced expression of HSP70 (spot 4) and GAPDH (spot 19) also contributes to the improvement of meat tenderness of broilers fed E. faecium.

Protein-protein interaction networks provide detailed information of the cellular mechanisms of tissues [94]. The proteins networked in the BIN were mainly involved in glycolysis and tight junction function in the post mortem muscle. This is consistent with that of GO enrichment and KEGG pathway analysis. Only four significantly enriched biological pathways (glycolysis/gluconeogenesis, pentose phosphate pathway, pyruvate metabolism, and tight junction) were observed in this study indicating the central role that they paly in improving meat quality of broilers supplemented with E. faecium. Some of the key node proteins that were highly linked in the BIN and enriched in GO term and KEGG pathway analyses were validated at a gene level. Protein abundances of LDHA, PGK1, FBP2 and CKMT2 which were consistent with mRNA levels provide potential targets for genetic manipulation of meat quality. 


\section{Conclusion}

E. faecium supplementation significantly improved the carcass properties and meat traits of broilers. This was reflected in the differential expression of proteins related to carbohydrate and energy metabolism, cytoskeleton, and molecular chaperones. These proteins are the major regulators of water holding capacity and $\mathrm{pH}$ of meat. With dietary E. faecium supplementation, expressions of proteins that improve meat quality were enhanced. These new findings increase our understanding of the mechanisms by which feeding probiotics improves chicken meat quality at the level of the proteome.

\section{Additional files}

Additional file 1: Table S1. The composition of broiler chicken starter and grower diets $(\mathrm{g} / \mathrm{kg})$.

Additional file 2: Table S2. Peptides identified from pectoral muscles of AA broiler chickens based on Mascot scores.

Additional file 3: Table S3. The primer sequences used for $\mathrm{QPCR}$ analysis of the differentially expressed proteins of the pectoral muscles of AA broiler chickens.

\section{Competing interests}

The authors declared that they have no competing interests.

\section{Authors' contributions}

BY and GHL designed the experiment, coordinated and supervised the research. AJZ, JJL and KM made the greatest contribution to the conduction of the experiment and analysis of data. SZ and $\mathrm{KL}$ assisted in the collection of samples. AJZ drafted the manuscript with the assistance of JKL, HYC and WLB. All authors read and approved the final manuscript.

\section{Acknowledgements}

This study was supported by the National Science and Technology Support Program of China (grant no. 2013BAD10B01-2), the China Modern Agriculture Research System (grant no. CARS-42), the National High Technology Research and Development Program of China (grant no. 2012AA022105), and the National Natural Science Foundation of China (grant no. 31101731).

\section{Author details}

'Key Laboratory of Feed Biotechnology of Ministry of Agriculture, Feed Research Institute, Chinese Academy of Agricultural Sciences, Beijing 100081, P. R. China. ${ }^{2}$ Key Laboratory of Pollinating Insect Biology of Ministry of Agriculture, Institute of Apicultural Research, Chinese Academy of Agricultural Sciences, Beijing 100081, P. R. China. ${ }^{3}$ School of Agriculture and Food Sciences, University of Queensland, Gatton, QLD 4343, Australia.

Received: 16 June 2014 Accepted: 16 December 2014

Published: 23 December 2014

\section{References}

1. Seal BS, Lillehoj HS, Donovan DM, Gay CG: Alternatives to antibiotics: a symposium on the challenges and solutions for animal production. Anim Health Res Rev 2013, 14:78-87.

2. Ponte PI, Prates JA, Crespo JP, Crespo DG, Mourao JL, Alves SP, Bessa RJ, Chaveiro-Soares MA, Ferreira LM, Fontes CM: Improving the lipid nutritive value of poultry meat through the incorporation of a dehydrated leguminous-based forage in the diet for broiler chicks. Poult Sci 2008, 87:1587-1594.

3. Givens I: Animal nutrition and lipids in animal products and their contribution to human intake and health. Nutrients 2009, 1:71-82.

4. Havenstein G, Ferket P, Qureshi M: Growth, livability, and feed conversion of 1957 versus 2001 broilers when fed representative 1957 and 2001 broiler diets. Poult Sci 2003, 82:1500-1508.
5. Havenstein G, Ferket P, Qureshi M: Carcass composition and yield of 1957 versus 2001 broilers when fed representative 1957 and 2001 broiler diets. Poult Sci 2003, 82:1509-1518.

6. Rance KA, McEntee GM, McDevitt RM: Genetic and phenotypic relationships between and within support and demand tissues in a single line of broiler chicken. Brit Poult Sci 2002, 43:518-527.

7. Fletcher DL: Broiler breast meat color variation, $\mathrm{pH}$, and texture. Poult Sci 1999, 78:1323-1327.

8. Baéza E: Measuring Quality Parameters. Poultry Meat and Processing Quality. Cambridge: Woodhead Publishing Limited; 2004.

9. Le Bihan-Duval $E$, Millet $N$, Remignon $\mathrm{H}$ : Broiler meat quality: effect of selection for increased carcass quality and estimates of genetic parameters. Poult Sci 1999, 78:822-826.

10. Strasburg GM, Chiang W: Pale, soft, exudative turkey-The role of ryanodine receptor variation in meat quality. Poult Sci 2009, 88:1497-1505.

11. Petracci M, Bianchi M, Cavani C: The European perspective on pale, soft, exudative conditions in poultry. Poult Sci 2009, 88:1518-1523.

12. Dransfield E, Sosnicki AA: Relationship between muscle growth and poultry meat quality. Poult Sci 1999, 78:743-746.

13. Barbut S: Pale, soft, and exudative poultry meat-Reviewing ways to manage at the processing plant. Poult Sci 2009, 88:1506-1512.

14. Pelicano E, Souza P, Souza H, Oba A, Norkus E, Kodawara L, Lima TD: Effect of different probiotics on broiler carcass and meat quality. Rev Bras Ciênc Avíco 2003, 5:207-214.

15. McClain PE, Mullins AM: Relationship of water binding and $\mathrm{pH}$ to tenderness of bovine muscles. J Anim Sci 1969, 29:268-271.

16. Judge MD, Cahill VR, Kunkle LE, Deatherage FE: Pork quality II. Physical, chemical and organoleptic relationships in fresh pork. J Anim Sci 1960, 19:145-149.

17. Wood JD, Enser M: Factors influencing fatty acids in meat and the role of antioxidants in improving meat quality. Brit J Nutr 1997, 78(Suppl 1):S49-60.

18. Jang A, Liu XD, Shin MH, Lee BD, Lee SK, Lee JH, Jo C: Antioxidative potential of raw breast meat from broiler chicks fed a dietary medicinal herb extract mix. Poult Sci 2008, 87:2382-2389.

19. Gladine C, Morand C, Rock E, Bauchart D, Durand D: Plant extracts rich in polyphenols (PERP) are efficient antioxidants to prevent lipoperoxidation in plasma lipids from animals fed n-3 PUFA supplemented diets. Anim Feed Sci Technol 2007, 136:281-296.

20. Rolfe RD: The role of probiotic cultures in the control of gastrointestinal health. J Nutr 2000, 130(2S Suppl):396S-402S.

21. Vali N, Samani A, Doosti A: Effect of probiotic on the laying performance of Japanese quails (Coturnix japonica). Res Opin Anim Vet Sci 2013, 3:218-220.

22. Shini S, Shini A, Blackall PJ: The potential for probiotics to prevent reproductive tract lesions in free-range laying hens. Anim Prod Sci 2013, 53:1298-1308.

23. Bozkurt M, Küçükyilmaz K, Ayhan V, Çabuk M, Çatlı AU: Performance of layer or broiler breeder hens varies in response to different probiotic preparations. Ital J Anim Sci 2011, 10:e31.

24. Tsirtsikos P, Fegeros K, Balaskas C, Kominakis A, Mountzouris KC: Dietary probiotic inclusion level modulates intestinal mucin composition and mucosal morphology in broilers. Poult Sci 2012, 91:1860-1868.

25. Dizaji B, Zakeri A, Golbazfarsad A, Faramarzy S, Ranjbari O: Influences of different growth promoters on intestinal morphology of broiler chickens. Eur J Exp Biol 2013, 3:32-37.

26. Ziaie $H$, Bashtani $M$, Torshizi M, Naeeimipour H, Zeinali $H$ : Effect of antibiotic and its alternatives on morphometric characteristics, mineral content and bone strength of tibia in ross broiler chickens. Global Vet 2011, 7:315-322.

27. Lourenço MC, Kuritza LN, Westphal P, Miglino LB, Pickler L, Kraieski AL, Santin E: Use of probiotic on T cell activation and Salmonella minnesota control in broilers. Pesquisa Vet Brasil 2013, 33:11-14.

28. Sterzo E, Paiva J, Mesquita A, Freitas Neto O, Berchieri A Jr: Organic acids and/or compound with defined microorganisms to control Salmonella enterica serovar Enteritidis experimental infection in chickens. Rev Bras Ciênc Avíco 2007, 9:69-73.

29. Ribeiro F, Jordan A, Mohnl M, Hulet M: Effects of multispecies probiotic on growth efficiency and performance of turkey hens. World Poultry Sci J 2012a, (Suppl 1):170-172.

30. Hosseini SA, Meimandipour A, Alami F, Mahdavi A, Mohiti-Asli M, Lotfollahian $H$, Cross D: Effects of ground thyme and probiotic supplements in diets on broiler performance, blood biochemistry and immunological response to sheep red blood cells. Ital J Anim Sci 2013, 12:e19. 
31. Abdel-Rahman H, Shawky S, Ouda H, Nafeaa A, Orabi S: Effect of two probiotics and bioflavonoids supplementation to the broilers diet and drinking water on the growth performance and hepatic antioxidant parameters. Global Vet 2013, 10:734-741.

32. Owings WJ, Reynolds DL, Hasiak RJ, Ferket PR: Influence of dietary supplementation with Streptococcus faecium M-74 on broiler body weight, feed conversion, carcass characteristics, and intestinal microbial colonization. Poult Sci 1990, 69:1257-1264.

33. Weis J, Hrnčár C, Pál G, Baraňska B, Bujko J, Malíková L: Effect of probiotic strain Enterococcus faecium M74 supplementation on the carcass parameters of different hybrid combination chickens. Anim Sci Biotechnol 2011, 44:149-152.

34. Endo J, Nakano M: Influence of a probiotic on productivity, meat components, lipid metabolism, caecal flora and metabolites, and raising environment in broiler production. Anim Sci J 1990, 70:207-218.

35. D'Alessandro A, Zolla L: Meat science: from proteomics to integrated omics towards system biology. J Proteomics 2013, 78:558-577.

36. Teltathum T, Mekchay S: Proteome changes in Thai indigenous chicken muscle during growth period. Int J Biol Sci 2009, 5:679-685.

37. Eckersall PD, de Almeida AM, Miller I: Proteomics, a new tool for farm animal science. J Proteomics 2012, 75:4187-4189.

38. Bendixen E, Danielsen M, Hollung K, Gianazza E, Miller I: Farm animal proteomics - a review. J Proteomics 2011, 74:282-293.

39. Wang T, Li A, Yi J, Tao H, Wang Y: Screening, identification and characterization of Enterococcus faecium for feed use. J Chin Cereal Oil Assoc 2010, 25:89-97.

40. Wang T, Li A, Tao H, Yi J: Study on the production technology and properties of microencapsulated Enterococcus faecium. J Northwest A\&F Univ (Nat Sci Ed) 2009, 37:51-62.

41. Group A: Arbor Acres Broiler Management Guide. Accessed May 2010. http://cn.aviagen.com/assets/Tech_Center/AA_Broiler/AA-BroilerHandbook2014i-EN.pdf.

42. Zhang L, Yue HY, Zhang HJ, Xu L, Wu SG, Yan HJ, Gong YS, Qi GH: Transport stress in broilers: I. Blood metabolism, glycolytic potential, and meat quality. Poult Sci 2009, 88:2033-2041.

43. Honikel KO: Reference methods for the assessment of physical characteristics of meat. Meat Sci 1998, 49:447-457.

44. Zhang WG, Lonergan SM, Gardner MA, Huff-Lonergan E: Contribution of postmortem changes of integrin, desmin and mu-calpain to variation in water holding capacity of pork. Meat Sci 2006, 74:578-585.

45. Remignon $H$, Desrosiers $V$, Marche $G$ : Influence of increasing breast meat yield on muscle histology and meat quality in the chicken. Reprod Nutr Dev 1996, 36:523-530.

46. Zhuang H, Savage EM: Comparison of cook loss, shear force, and sensory descriptive profiles of boneless skinless white meat cooked from a frozen or thawed state. Poult Sci 2013, 92:3003-3009.

47. Jaturasitha S, Srikanchai T, Kreuzer M, Wicke M: Differences in carcass and meat characteristics between chicken indigenous to northern Thailand (Black-boned and Thai native) and imported extensive breeds (Bresse and Rhode Island Red). Poult Sci 2008, 87:160-169.

48. Saláková A, Straková E, Válková V, Buchtová H, Steinhauserová I: Quality indicators of chicken broiler raw and cooked meat depending on their sex. Acta Vet Brno 2009, 78:497-504.

49. Fletcher $\mathrm{DL}$, Qiao M, Smith DP: The relationship of raw broiler breast meat color and pH to cooked meat color and pH. Poult Sci 2000, 79:784-788.

50. Luo J, Zheng A, Meng K, Chang W, Bai Y, Li K, Cai H, Liu G, Yao B: Proteome changes in the intestinal mucosa of broiler (Gallus gallus) activated by probiotic Enterococcus faecium. J Proteomics 2013, 91:226-241.

51. Lu Y, Liu X, Shi S, Su H, Bai X, Cai G, Yang F, Xie Z, Zhu Y, Zhang Y: Bioinformatics analysis of proteomic profiles during the process of anti-Thy1 nephritis. Mol Cell Proteomics 2012, 11:M111.008755.

52. Bindea G, Mlecnik B, Hackl H, Charoentong P, Tosolini M, Kirilovsky A Fridman WH, Trajanoski Z, Galon J: ClueGO: a Cytoscape plug-in to decipher functionally grouped gene ontology and pathway annotation networks. Bioinformatics 2009, 25:1091-1093.

53. Szklarczyk D, Franceschini A, Kuhn M, Simonovic M, Roth A, Minguez $P$, Doerks T, Stark M, Muller J, Bork P: The STRING database in 2011: functional interaction networks of proteins, globally integrated and scored. Nucleic Acids Res 2011, 39(suppl 1):D561-D568.

54. Livak KJ, Schmittgen TD: Analysis of relative gene expression data using real-time quantitative PCR and the $2^{-\Delta \Delta C T}$ method. Methods 2001, 25:402-408
55. Bustin SA, Benes V, Garson JA, Hellemans J, Huggett J, Kubista M, Mueller R, Nolan T, Pfaffl MW, Shipley GL: The MIQE guidelines: minimum information for publication of quantitative real-time PCR experiments. Clin Chem 2009, 55:611-622.

56. Demeterova M, Mariscakova R, Pistl J, Nad P, Samudovska A: The effect of the probiotic strain Enterococcus faecium DSM 7134 in combination with natural humic substances on performance and health of broiler chickens. Berl Munch Tierarztl Wochenschr 2009, 122:370-377.

57. Ouali A: Proteolytic and physicochemical mechanisms involved in meat texture development. Biochimie 1992, 74:251-265.

58. Schreurs FJG: Post-mortem changes in chicken muscle. World Poultry Sci J 2000, 56:319-346.

59. Poso AR, Puolanne E: Carbohydrate metabolism in meat animals. Meat Sci 2005, 70:423-434.

60. Najjar VA, Pullman ME: The occurrence of a group transfer involving enzyme (phosphoglucomutase) and substrate. Science 1954, 119:631-634.

61. Marcus F, Gontero B, Harrsch PB, Rittenhouse J: Amino acid sequence homology among fructose-1,6-bisphosphatases. Biochem Bioph Res Co 1986, 135:374-381.

62. Marcus F, Harrsch PB: Amino acid sequence of spinach chloroplast fructose-1,6-bisphosphatase. Arch Biochem Biophys 1990, 279:151-157.

63. Bowker BC, Grant AL, Forrest JC, Gerrard DE: Muscle metabolism and PSE pork. J Anim Sci 2000, 79(suppl 1):1-8.

64. D’Alessandro A, Marrocco C, Rinalducci S, Mirasole C, Failla S, Zolla L: Chianina beef tenderness investigated through integrated Omics. J Proteomics 2012, 75:4381-4398.

65. Okumura T, Yamada R, Nishimura T: Survey of conditioning indicators for pork loins: changes in myofibrils, proteins and peptides during postmortem conditioning of vacuum-packed pork loins for 30 days. Meat Sci 2003, 64:467-473.

66. Guillemin N, Bonnet M, Jurie C, Picard B: Functional analysis of beef tenderness. J Proteomics 2011, 75:352-365.

67. Pancholi V: Multifunctional alpha-enolase: its role in diseases. Cell Mol Life Sci 2001, 58:902-920.

68. Smith RM, Galbler NK, Young JM, Cai W, Boddicker NJ, Anderson MJ, Huff-Lonergan E, Dekkers JC, Lonergan SM: Effect of selection for reduced residual feed intake on composition and quality of fresh pork. J Anim Sci 2011, 89:192-200.

69. Morzel M, Chambon C, Hamelin M, Santé-Lhoutellier V, Sayd T, Monin G: Proteome changes during pork meat ageing following use of two different pre-slaughter handling procedures. Meat Sci 2004, 67:689-696.

70. Goldblatt $H$ : The effect of high salt intake on the blood pressure of rabbits. Lab Invest 1969, 21:126-128.

71. D'Alessandro A, Marrocco C, Zolla V, D'Andrea M, Zolla L: Meat quality of the longissimus lumborum muscle of Casertana and Large White pigs: metabolomics and proteomics intertwined. J Proteomics 2011, 75:610-627.

72. Robson RM: Myofibrillar and cytoskeletal structures and proteins in mature skeletal muscle cells. Utrecht: ECCEAMST; 1995.

73. Koohmaraie M, Shackelford SD, Wheeler TL, Lonergan SM, Doumit ME: A muscle hypertrophy condition in lamb (callipyge): characterization of effects on muscle growth and meat quality traits. J Anim Sci 1995 73:3596-3607

74. Marinus FW, Jansen J, Broekman KCJA, Reimert H, Heuven HCM: Postmortem proteome degradation profiles of longissimus muscle in Yorkshire and Duroc pigs and their relationship with pork quality traits. Meat Sci 2009, 83:744-751.

75. Melody JL, Lonergan SM, Rowe LJ, Huiatt TW, Mayes MS, Huff-Lonergan E: Early postmortem biochemical factors influence tenderness and waterholding capacity of three porcine muscles. J Anim Sci 2004, 82:1195-1205.

76. Morrison EH, Mielche MM, Purslow PP: Immunolocalisation of intermediate filament proteins in porcine meat. Fibre type and muscle-specific variations during conditioning. Meat Sci 1998, 50:91-104.

77. Xiong YL: Protein Functionality. Oxford: Elsevier Academic Press; 2004

78. Huff-Lonergan E, Lonergan S: Postmortem Mechanisms of Meat Tenderization. In Quality Attributes of Muscle Foods. Edited by Xiong Y, Chi-Tang H, Shahidi F. United States: Springer; 1999:229-251.

79. Kendall TL, Koohmaraie M, Arbona JR, Williams SE, Young LL: Effect of pH and ionic strength on bovine m-calpain and calpastatin activity. J Anim Sci 1993, 71:96-104.

80. Cornforth DP: Quality Attributes and their Measurement in Meat, Poultry, and Fish Products. London: Chapman and Hall; 1994. 
81. Allen CD, Fletcher DL, Northcutt JK, Russell SM: The relationship of broiler breast color to meat quality and shelf-life. Poult Sci 1998, 77:361-366.

82. Barbut $\mathrm{S}$ : Colour measurements for evaluating the pale soft exudative (PSE) occurrence in turkey meat. Food Res Int 1993, 26:39-43.

83. Allen CD, Russell SM, Fletcher DL: The relationship of broiler breast meat color and pH to shelf-life and odor development. Poult Sci 1997, 76:1042-1046

84. Sayd T, Morzel M, Chambon C, Franck M, Figwer P, Larzul C, Le Roy P, Monin $G$, Cherel P, Laville E: Proteome analysis of the sarcoplasmic fraction of pig semimembranosus muscle: implications on meat color development. J Agric Food Chem 2006, 54:2732-2737.

85. D'Alessandro A, Rinalducci S, Marrocco C, Zolla V, Napolitano F, Zolla L: Love me tender: an Omics window on the bovine meat tenderness network. J Proteomics 2012, 75:4360-4380.

86. Lomiwes D, Farouk MM, Wiklund E, Young OA: Small heat shock proteins and their role in meat tenderness: a review. Meat Sci 2014, 96:26-40

87. Mayer MP, Bukau B: Hsp70 chaperones: cellular functions and molecular mechanism. Cell Mol Life Sci 2005, 62:670-684.

88. Ouali A, Gagaoua M, Boudida Y, Becila S, Boudjellal A, Herrera-Mendez CH, Sentandreu MA: Biomarkers of meat tenderness: present knowledge and perspectives in regards to our current understanding of the mechanisms involved. Meat Sci 2013, 95:854-870.

89. Lomiwes D, Farouk MM, Frost DA, Dobbie PM, Young OA: Small heat shock proteins and toughness in intermediate pHu beef. Meat Sci 2013, 95:472-479.

90. Tavaria M, Gabriele T, Kola I, Anderson RL: A hitchhiker's guide to the human Hsp70 family. Cell Stress Chaperon 1996, 1:23-28.

91. Hwang IH, Park BY, Kim JH, Cho SH, Lee JM: Assessment of postmortem proteolysis by gel-based proteome analysis and its relationship to meat quality traits in pig longissimus. Meat Sci 2005, 69:79-91.

92. van de Wiel DF, Zhang WL: Identification of pork quality parameters by proteomics. Meat Sci 2007, 77:46-54.

93. Laville E, Sayd T, Terlouw C, Blinet S, Pinguet J, Fillaut M, Glenisson J, Cherel P: Differences in pig muscle proteome according to HAL genotype: implications for meat quality defects. J Agric Food Chem 2009, 57:4913-4923.

94. Bonetta L: Protein-protein interactions: interactome under construction. Nature 2010, 468:851-854.

doi:10.1186/1471-2164-15-1167

Cite this article as: Zheng et al:: Proteome changes underpin improved meat quality and yield of chickens (Gallus gallus) fed the probiotic Enterococcus faecium. BMC Genomics 2015 15:1167.

\section{Submit your next manuscript to BioMed Central and take full advantage of:}

- Convenient online submission

- Thorough peer review

- No space constraints or color figure charges

- Immediate publication on acceptance

- Inclusion in PubMed, CAS, Scopus and Google Scholar

- Research which is freely available for redistribution 